\title{
The Restoration History Manuscript Collection
}

\author{
PaUl M. EdWARdS
}

IN JUNE of 1844, Joseph Smith, Jr., the founder of Mormonism, was killed by a mob at Carthage Jail in Illinois. In the troubled times that followed, most of the members of the church left their homes in Nauvoo, Illinois, and headed west. Under the leadership of Brigham Young, president of the Quorum of Twelve, these harassed converts sought a land where they would be unmolested and where they could practice their beliefs in relative safety. The first step for the refugees was to cross the river into Iowa where they paused to prepare for the trip west. One has only to follow the Mormon Trail across the state to recognize the impact that this exodus was to make on Iowa. The settlements along the way, especially Winter Quarters and Council Bluffs, were permanently marked by these refugees. This migration to Utah has been well recorded as a part of the larger "westward movement."

A significant number of Mormons, however, did not head west; many remained in the Midwest and Great Plains. Iowa was to be important to these church members. Decatur County in particular has long been associated with Mormon history. The earliest of its pioneers were also refugees who, coming from Nauvoo in 1846, stopped at Garden Grove on their trip west. Some stayed only for the winter, but some became permanent residents. Others gathered near Little River at a place now called Pleasanton. In the next ten years many of these scattered people were joined together in a reorganization of the Mormon church under the leadership of the martyr's son, Joseph Smith III. This body - the Reorganized Church of Jesus Christ of Latter Day Saints-had its first headquarters in Plano, Illinois, but by 1869 the Reorganization was looking for a more suitable location. In 


\section{The Annals of Iowa}

1870, under the direction of the First United Order of Enoch, a settlement was organized in Fayette Township, Decatur County; this settlement was later incorporated as Lamoni. By 1881, the church headquarters had been moved to Lamoni and remained there for nearly thirty years.

One result of the move to Decatur County was the establishment, in 1895, of Graceland College as a four-year nonsectarian liberal arts institution. Another was the development of the church's publishing arm in Lamoni. Since this time, the Reorganization has had very strong ties in Iowa and a good deal of the history of the movement relates closely to the history of the state. The history of the Reorganization and those others who did not head west has never been well developed. It was to fill this void that the Restoration History Manuscript Collection was developed. ${ }^{1}$

This unique collection includes archival and secondary library materials dealing with the Reorganized Church of Jesus Christ of Latter Day Saints, the church in Iowa, and the histories of Lamoni, Decatur County, and Graceland College. Archival materials fill approximately 740 shelf feet; the published materials comprise nearly 6,500 volumes. This body of materials was originally organized privately by Paul M. Edwards; Graceland College assumed responsibility for the collection in 1972. Since that time, the college has been instrumental in the growth and protection of this material which is separately housed, cataloged, and serviced within the Frederick Madison Smith Library on Graceland's campus.

ThE MAIN BODY of materials in the Restoration History Manuscript Collection deals primarily with the founding and development of the Reorganization from 1844 to the present. This information is supplemented by sources dealing with the birth of the movement (1824-1844), the American religious climate at that time, the place of the Mormon movement within

1. The RLDS church is known to its members as the Restoration, from their belief that this church is a restoration of the original church of Christ which went into apostasy during the Dark Ages. The term can refer to the entire Mormon movement, whether it be in Utah, Independence, or one of the many dispersions. Thus, the collection is named the Restoration History Manuscript Collection. 
the mainstream of religious thought, and contemporary records of the Reorganization within Iowa. It also includes an excellent compilation of scripture and pseudo-scripture that has been associated with various elements of the movement, including rare and scarce editions of the Book of Mormon, the Inspired Version of the Bible, the Doctrine and Covenants, Rules of Order, the Book of Jasher, and Book of Commandments. In addition, the main materials boast a large theme-related periodical collection (in several languages); several thousand photographs; numerous diaries, letterpress books, and sets of correspondence; and official records of church institutions.

The larger archives also serves as an umbrella for a series of internal collections which give breadth to research in this area. These include the extensive Alice M. Smith Edwards correspondence, photographs, and manuscript materials-around 9 shelf feet. Edwards was the daughter of Frederick M. Smith, the second president of the Reorganization, and a greatgranddaughter of Joseph Smith, the founder. She was married to F. H. Edwards, a long-time member of the First Presidency of the church. Alice Edwards was a poet and author and published numerous works dealing with the church and in areas of her own personal interests.

The private collections of several church leaders are included as well. The materials of Harold Veldt, a life-long missionary and prolific chronicler, fill 29 shelf feet. His papers and diaries are a nearly complete record of over forty years as a missionary. The Wicks/Weld Collection of letters, diaries, and papers of two Lamoni citizens and early church members-approximately 9 shelf feet-gives considerable insight into the town-church relationship while the headquarters was in Lamoni. The church physician, Charles Grabski, has placed his collection of primary materials and scarce secondary works relating to the growth of the church from 1925 to 1965 with the college; this collection fills 23 shelf feet. Arthur Du Rose, donor of the space which houses the collection, has deposited early books and manuscript materials dealing with the early Christian movement in the United States. This series-24 shelf feet-includes early Bibles and works on the early martyrs.

As supportive materials for those interested in the Mormon movement, the collection houses a library of dispersion periodi- 


\section{The Annals of Iowa}

cals. The Restoration has given birth to hundreds of dispersions. A large number of these published periodicals either add to the history of the movement or have served as critics of the movements that now exist.

The Restoration History Manuscript Collection also includes four living archives. It houses the papers of the John Whitmer Historical Association, a society devoted to the history of the Reorganization. These papers include a complete set of the John Whitmer lectures that have been offered at Graceland for the past nine years, papers presented at the annual meetings of the society, the papers of its past presidents, and all correspondence concerning the society. Currently the Whitmer Association papers occupy 16 shelf feet.

The papers of Venture Foundation are housed in the collection as well. This foundation, located in Lamoni, published Courage: A Journal of History, Thought and Action. These papers-approximately 13 shelf feet-include correspondence, articles, and financial records, and contain a great deal of information on the liberal movement within the church in the late 1960s and early 1970s.

A third living archives is the manuscript collection of unpublished works dealing with the Reorganization. As interest increases in the church and its place in Iowa, more research papers are written and read at conferences, more books on the movement are reviewed, and more incidental works on local history are developed. Most of this very valuable material-226 shelf feet-would not be available in any other form.

And finally, the collection maintains the archives of Graceland College-173 shelf feet. Like any institution, Graceland creates masses of paper work. This material is preserved as a living record of the growth of the college and the contribution it and its students and faculty make to the community and the church.

The job of documenting our roots is most difficult and yet increasingly significant to us all. The Restoration History Manuscript Collection consolidates much general history of the Mormon movement. But it is directed toward more than that. It is an excellent example of the relationship between national and local history. All history-no matter how globally significant the events-is, in the final analysis, the history of a people in a 


\section{Restoration History}

particular place. The Restoration History Manuscript Collection provides valuable insights into the relationship between the religious movement that is represented by the followers of Joseph Smith and the developing history of the environment in which much of that history has taken place. This collection represents an expanding source of material for those interested both in lowa and in the Reorganization.

The Restoration History Manuscript Collection is housed in the Frederick Madison Smith Library, Graceland College, Lamoni, Iowa 50140. It is open from September through May from 9:00 a.m. to 4:30 p.m. During the summer months it is open by appointment only. 
Copyright of Annals of Iowa is the property of State of Iowa, by \& through the State Historical Society of Iowa and its content may not be copied or emailed to multiple sites or posted to a listserv without the copyright holder's express written permission. However, users may print, download, or email articles for individual use. 